\title{
PENGARUH PENAMBAHAN BAHAN ADMIXTURE CONSOL SG TERHADAP KUAT TEKAN BETON
}

\author{
Arifien Nursandah ${ }^{1)}$, Satriyo utomo ${ }^{2)}$, Dio Alif Hutama ${ }^{3)}$ \\ 1) Prodi Teknik Sipil, Fakultas Teknik, Universitas Muhammadiyah Surabaya \\ JL. Sutorejo No. 59 Kota Surabaya, Jawa Timur, 61135 \\ E-mail: arifien.nursandah@gmail.com \\ 2) Prodi Teknik Sipil, Fakultas Teknik, Universitas Muhammadiyah Surabaya \\ JL. Sutorejo No. 59 Kota Surabaya, Jawa Timur, 61135 \\ E-mail: satrioutomo64@gmail.com \\ ${ }^{3)}$ Prodi Teknik Sipil, Fakultas Teknik, Universitas Muhammadiyah Surabaya \\ JL. Sutorejo No. 59 Kota Surabaya, Jawa Timur, 61135 \\ E-mail: dioalifhutama@ft.um-surabaya.ac.id
}

\begin{abstract}
Concrete is a building material that is very popularly used in the world of construction services, along with the rapid development of concrete technology has been successfully developed various innovation on additive material in concrete mixes to get good quality concrete. Consol SG is an additive material or admixture which is a product of liquid concrete plasticizers and high water reducing agents by regulating the effect of retarding, can increase workability without increasing water content, reducing water without losing workability, and increasing compressive strength, and chloride free with no damaging on reinforcement. This research used an experimental method in a laboratory with a total of 60 samples of specimens, concrete compressive strength at 28 days with a cylinder diameter of $150 \mathrm{~mm}$ high by $300 \mathrm{~mm}$ with a variation of Consol SG mixture of $0 \%, 0.2 \%$ and $0.3 \%$ with high quality planned $\mathrm{f}^{\prime} \mathrm{c}=30 \mathrm{MPa}$, on the effect of Consol SG addition on the compressive strength of the concrete which is viewed from the variation of Consol SG mixture. The results of the concrete compressive strength value of Consol SG $0.2 \%$ is $31.13 \mathrm{MPa}$ (up to $2.54 \%$ in terms of normal concrete), for the variation of Consol SG $0.3 \%$ mixture of $32.25 \mathrm{MPa}$ (up to $6.22 \%$ in terms of normal concrete). While the variation of $0.2 \%$ to $0.3 \%$ increased by $(3.59 \%)$. The test of the statistical model used is the Chi-Square test and the T-test using the SPSS software.
\end{abstract}

Keywords: Additive, Consol SG, Compressive Strength of Concrete.

\begin{abstract}
Abstrak
Beton merupakan bahan bangunan yang sangat populer digunakan dalam dunia jasa konstruksi, seiring pesatnya perkembangan teknologi beton telah berhasil dikembangkan berbagai inovasi bahan tambah dalam campuran beton agar mendapatkan beton yang berkualitas baik. Consol SG adalah bahan tambah admixtures atau additive merupakan produk plasticizer beton cair dan agen pereduksi air yang tinggi dengan mengatur efek perlambatan, dapat meningkatan kemampuan kerja tanpa meningkatkan kadar air, mengurangi air tanpa kehilangan kemampuan kerja, dan meningkatkan kuat tekan, serta bebas klorida yang tidak merusak pada tulangan. Penelitian ini menggunakan metode eksperimen dilaboratorium dengan total benda uji 60 sampel, kuat tekan beton pada umur 28 hari dengan diameter silinder ukuran $150 \mathrm{~mm}$ tinggi $300 \mathrm{~mm}$ dengan variasi campuran Consol SG sebanyak $0 \%, 0,2 \%$ dan $0,3 \%$ dengan mutu yang direncanakan $\mathrm{f}^{\prime} \mathrm{c}=30 \mathrm{MPa}$, pada pengaruh penambahan Consol SG terhadap kuat tekan beton yang ditinjau dari variasi campuran Consol SG. Hasil nilai kuat tekan beton pada campuran Consol SG 0,2\% sebesar 31,13 MPa (naik 2,54\% ditinjau dari beton normal), untuk variasi campuran Consol SG 0,3\% sebesar 32,25 MPa (naik 6,22\% ditinjau dari beton normal). Sedangkan variasi $0,2 \%$ ke $0,3 \%$ naik sebesar $(3,59 \%)$. Pengujian model statistik yang digunakan adalah uji Chi-Kuadrat dan uji T menggunakan aplikasi SPSS.
\end{abstract}

Kata Kunci: Additive, Consol SG, Kuat Tekan Beton.

\section{PENDAHULUAN}

Beton merupakan bahan bangunan yang sangat populer digunakan dalam dunia jasa konstruksi, disamping materialnya yang mudah didapat juga kemudahan dalam pengerjaan merupakan salah satu keunggulan dari beton. Penggunaan beton menjadi pilihan utama karena beton terbentuk dari bahan campuran berupa agregat halus dan kasar serta bahan tambah admixture atau additivie, dengan menambahkan semen secukupnya berfungsi sebagai perekat bahan penyusun beton dan air sebagai bahan pembantu untuk proses reaksi kimia.

Consol SG produk buatan anak bangsa, merupakan produk plasticizer beton cair dan agen pereduksi air yang tinggi dengan mengatur efek perlambatan. Consol SG digunakan sebagai bahan percampuran beton dengan tujuan menempatkan kondisi pada permukaann beton yang rata, beton yang dipompa, suhu tinggi, dan beton readymix serta area dimana volume besar harus ditempatkan pada satu waktu, dan Consol SG dapat menambah pengaturan waktu dalam cuaca panas, sehingga dapat meningkatan kemampuan kerja tanpa meningkatkan kadar air, mengurangi air tanpa kehilangan kemampuan kerja, dan meningkatkan kuat tekan, serta bebas klorida yang tidak merusak pada tulangan (www. Kimia kontruksi Indonesia.com). Berdasarkan uraian di atas maka dilakukan penelitian untuk mengetahui pengaruh penambahan Consol SG terhadap kuat tekan beton yang dihasilkan. 


\section{METODE PENELITIAN}

Penelitian ini adalah penelitian eksperimen dengan mengadakan suatu percobaan secara langsung untuk mendapatkan suatu data atau hasil yang menghubungkan antara variable-variabel yang diselidiki. Tahapan penelitian ditunjukkan pada gambar berikut:

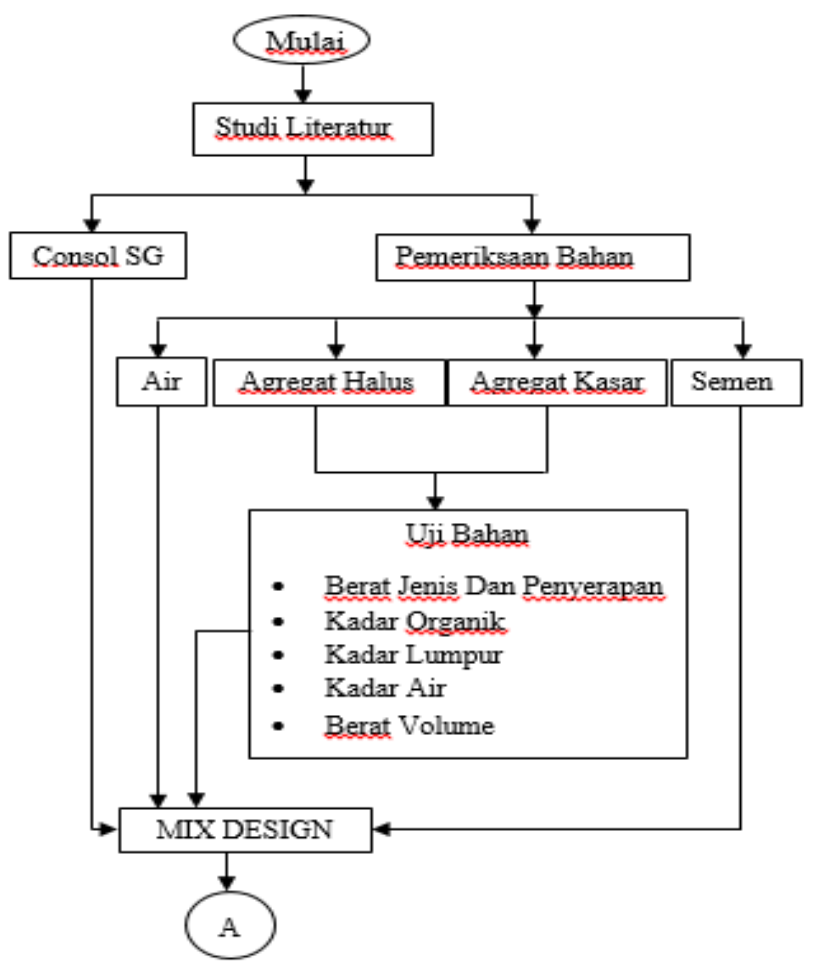

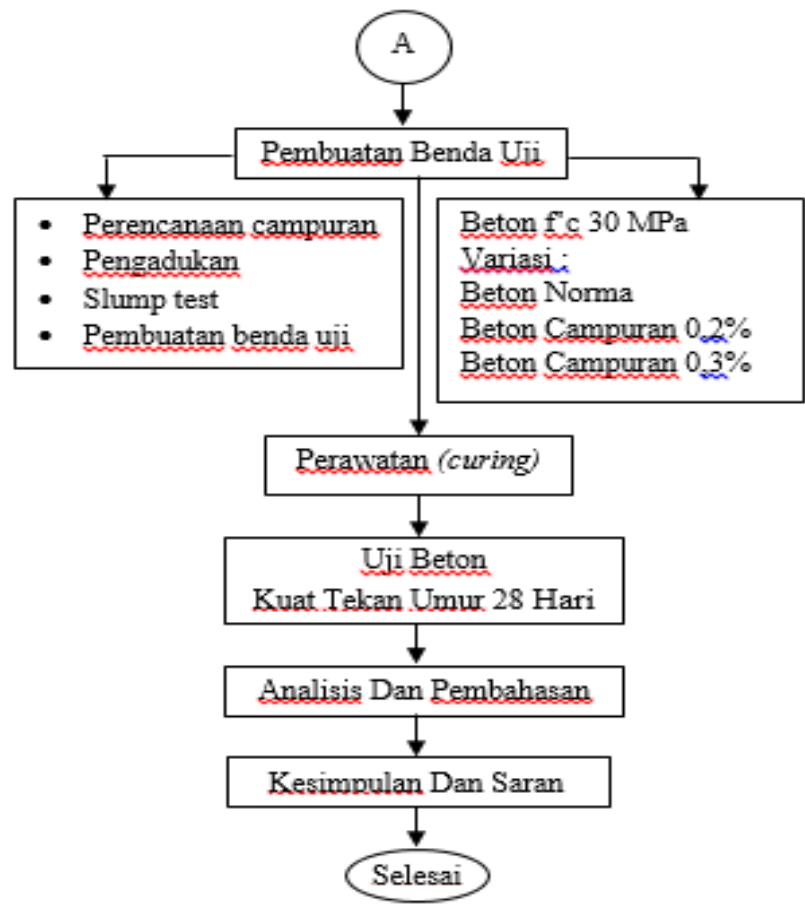

Gambar 3.1 Bagan Alur Tahapan

Benda Uji

Benda uji yang digunakan dalam penelitian menggunakan silinder yang mempunyai ukuran diameter $150 \mathrm{~mm}$ dan tinggi $300 \mathrm{~mm}$. Untuk benda uji berjumlah 60 sampel dimana setiap variasi terdiri dari 20 sampel uji kuat tekan normal dan penambahan Consol SG, sedangan pengujian dilakukan pada berumur 28 hari. Berikut adalah rincian benda uji dapat dilihat di Tabel 1 .

Tabel 1. Rencana benda uji

\begin{tabular}{|c|c|c|c|c|c|c|}
\hline No. & \multicolumn{2}{|c|}{ Variasi } & $\begin{array}{c}\text { Jenis } \\
\text { Pengujian }\end{array}$ & Kode & $\begin{array}{c}\text { Benda } \\
\text { Uji }\end{array}$ & Jumlah \\
\hline 1. & \multicolumn{2}{|c|}{ Beton Normal } & Kuat Tekan & $\mathrm{BN}$ & Silinder & 20 \\
\hline 2. & \multirow{3}{*}{ Consol SG } & $0,2 \%$ & Kuat Tekan & $\mathrm{BC}$ & Silinder & 20 \\
\hline \multirow[t]{2}{*}{3.} & & $0,3 \%$ & Kuat Tekan & $\mathrm{BC}$ & Silinder & 20 \\
\hline & & & & \multicolumn{2}{|c|}{ Jumlah Total Benda Uji } & 60 \\
\hline
\end{tabular}

Sumber: Analisis Data (2018)

Keterangan:

$\mathrm{BN}$ : Benda uji silinder mengunakan campuran normal.

$\mathrm{BC}$ : Benda uji silinder mengunakan tambahan Consol SG.

\section{HASIL DAN PEMBAHASAN}

Berdasarkan analisis pengujian agregat yang telah semua memenui persyaratan SNI dan mix design telah melampaui kuat tekan yang direncanakan $30 \mathrm{MPa}$, maka untuk pengecoran sampel digunakan agregat kasar dari Situbondo dan agregat halus dari Badas Kediri. 


\section{Hasil Mix Design Beton Campuran Consol SG 1 m $^{3}$}

Tabel 2. Perhitungan Mix Design Consol SG $1 \mathrm{~m}^{3}$

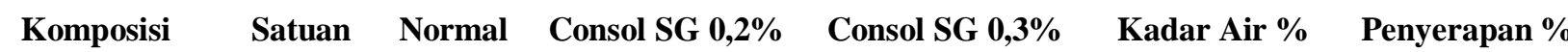

\begin{tabular}{lcccccc}
\hline Air & $\mathrm{kg} / \mathrm{m}^{3}$ & 190 & 159 & 159 & & \\
\hline Semen & $\mathrm{kg} / \mathrm{m}^{3}$ & 385 & 385 & 385 & 7,56 & 2,733 \\
\hline Agregat Halus & $\mathrm{kg} / \mathrm{m}^{3}$ & 612 & 642 & 642 & 1,75 & 1,643 \\
\hline Agregat Kasar & $\mathrm{kg} / \mathrm{m}^{3}$ & 1243 & 1244 & 0,99 & & \\
\hline Consol SG & $\mathrm{kg} / \mathrm{m}^{3}$ & - & 0,66 & & & \\
\hline Jumlah & $\mathrm{kg} / \mathrm{m}^{3}$ & 2430 & & & & \\
\hline
\end{tabular}

Sumber: Analisis Data (2018)

\section{Hasil Pengujian Kuat Tekan Beton}

Tabel 3. Rekapitulasi Hasil Pengujian Kuat Tekan Beton

\begin{tabular}{|c|c|c|c|c|c|c|c|c|c|}
\hline \multirow[t]{2}{*}{ No. } & \multirow{2}{*}{$\begin{array}{c}\text { Kode } \\
\text { Benda } \\
\text { Ujii }\end{array}$} & \multicolumn{2}{|c|}{ Tanggal } & \multirow[t]{2}{*}{$\begin{array}{l}\text { Umur } \\
\text { (Hari) }\end{array}$} & \multirow[t]{2}{*}{$\begin{array}{l}\text { Slump } \\
(\mathbf{c m})\end{array}$} & \multirow[t]{2}{*}{$\begin{array}{c}\text { Berat } \\
(\mathrm{kg})\end{array}$} & \multirow{2}{*}{$\begin{array}{c}\text { Force } \\
\text { Pressure } \\
(\mathbf{k N})\end{array}$} & \multicolumn{2}{|c|}{$\begin{array}{c}\text { Silinder } \\
\text { Kuat Tekan }\end{array}$} \\
\hline & & Pengecoran & Pengujian & & & & & $\left(\mathrm{kg} / \mathrm{cm}^{2}\right)$ & (MPa) \\
\hline 1. & $\mathrm{BN}-1$ & 29 April 2018 & 26 Mei 2018 & 28 & 7,5 & 12,78 & 530 & 305,92 & 30,59 \\
\hline 2. & $\mathrm{BN}-2$ & 29 April 2018 & 26 Mei 2018 & 28 & 7,5 & 12,75 & 525 & 303,04 & 30,30 \\
\hline 3. & $\mathrm{BN}-3$ & 29 April 2018 & 26 Mei 2018 & 28 & 7,5 & 12,75 & 525 & 303,04 & 30,30 \\
\hline 4. & $\mathrm{BN}-4$ & 29 April 2018 & 26 Mei 2018 & 28 & 7,5 & 12,69 & 515 & 297,27 & 29,72 \\
\hline 5. & $\mathrm{BN}-5$ & 29 April 2018 & 26 Mei 2018 & 28 & 7,5 & 12,69 & 520 & 300,15 & 30,02 \\
\hline 6. & BN-6 & 29 April 2018 & 26 Mei 2018 & 28 & 7,5 & 12,65 & 530 & 305,92 & 30,59 \\
\hline 7. & $\mathrm{BN}-7$ & 29 April 2018 & 26 Mei 2018 & 28 & 7,5 & 12,70 & 515 & 297,27 & 29,72 \\
\hline 8. & $\mathrm{BN}-8$ & 29 April 2018 & 26 Mei 2018 & 28 & 7,5 & 12,78 & 530 & 305,92 & 30,59 \\
\hline 9. & BN-9 & 29 April 2018 & 26 Mei 2018 & 28 & 7,5 & 12,78 & 530 & 305,92 & 30,59 \\
\hline 10. & $\mathrm{BN}-10$ & 29 April 2018 & 26 Mei 2018 & 28 & 7,5 & 12,80 & 545 & 314,58 & 31,46 \\
\hline 11. & $\mathrm{BN}-11$ & 30 April 2018 & 27 Mei 2018 & 28 & 7,5 & 12,68 & 520 & 300,15 & 30,02 \\
\hline 12. & $\mathrm{BN}-12$ & 30 April 2018 & 27 Mei 2018 & 28 & 7,5 & 12,77 & 525 & 303,04 & 30,30 \\
\hline 13. & $\mathrm{BN}-13$ & 30 April 2018 & 27 Mei 2018 & 28 & 7,5 & 12,70 & 520 & 300,15 & 30,02 \\
\hline 14. & $\mathrm{BN}-14$ & 30 April 2018 & 27 Mei 2018 & 28 & 7,5 & 12,81 & 535 & 308,81 & 30,88 \\
\hline 15. & $\mathrm{BN}-15$ & 30 April 2018 & 27 Mei 2018 & 28 & 7,5 & 12,70 & 520 & 303,15 & 30,02 \\
\hline 16. & $\mathrm{BN}-16$ & 30 April 2018 & 27 Mei 2018 & 28 & 7,5 & 12,70 & 520 & 300,15 & 30,30 \\
\hline 17. & $\mathrm{BN}-17$ & 30 April 2018 & 27 Mei 2018 & 28 & 7,5 & 12,76 & 525 & 303,04 & 30,02 \\
\hline 18. & BN-18 & 30 April 2018 & 27 Mei 2018 & 28 & 7,5 & 12,78 & 530 & 305,92 & 30,59 \\
\hline 19. & $\mathrm{BN}-19$ & 30 April 2018 & 27 Mei 2018 & 28 & 7,5 & 12,75 & 535 & 308,81 & 30,88 \\
\hline 20. & BN-20 & 30 April 2018 & 27 Mei 2018 & 28 & 7,5 & 12,81 & 525 & 303,04 & 30,30 \\
\hline 21. & $\mathrm{BC} 0,2-1$ & 01 Mei 2018 & 28 Mei 2018 & 28 & 7,5 & 12,83 & 545 & 314,58 & 31,46 \\
\hline 22. & $\mathrm{BC} 0,2-2$ & 01 Mei 2018 & 28 Mei 2018 & 28 & 7,5 & 12,65 & 530 & 305,92 & 30,59 \\
\hline 23. & $\mathrm{BC} 0,2-3$ & 01 Mei 2018 & 28 Mei 2018 & 28 & 7,5 & 12,65 & 530 & 305,92 & 30,59 \\
\hline 24. & $\mathrm{BC} 0,2-4$ & 01 Mei 2018 & 28 Mei 2018 & 28 & 7,5 & 12,69 & 535 & 308,81 & 30,02 \\
\hline 25. & $\mathrm{BC} 0,2-5$ & 01 Mei 2018 & 28 Mei 2018 & 28 & 7,5 & 12,75 & 540 & 311,70 & 31,17 \\
\hline 26. & BC0,2-6 & 01 Mei 2018 & 28 Mei 2018 & 28 & 7,5 & 12,65 & 530 & 305,92 & 30,59 \\
\hline 27. & $\mathrm{BC} 0,2-7$ & 01 Mei 2018 & 28 Mei 2018 & 28 & 7,5 & 12,84 & 545 & 314,58 & 31,46 \\
\hline 28. & $\mathrm{BC} 0,2-8$ & 01 Mei 2018 & 28 Mei 2018 & 28 & 7,5 & 12,87 & 550 & 317,47 & 31,75 \\
\hline 29. & $\mathrm{BC} 0,2-9$ & 01 Mei 2018 & 28 Mei 2018 & 28 & 7,5 & 12,78 & 540 & 311,70 & 31,17 \\
\hline 30. & $\mathrm{BC} 0,2-10$ & 01 Mei 2018 & 28 Mei 2018 & 28 & 7,5 & 12,64 & 530 & 305,92 & 30,59 \\
\hline 31. & $\mathrm{BC} 0,2-11$ & 02 Mei 2018 & 29 Mei 2018 & 28 & 7,5 & 12,84 & 545 & 314,58 & 30,88 \\
\hline
\end{tabular}




\begin{tabular}{|c|c|c|c|c|c|c|c|c|c|}
\hline \multirow[t]{2}{*}{ No. } & \multirow{2}{*}{$\begin{array}{c}\text { Kode } \\
\text { Benda } \\
\text { Uji }\end{array}$} & \multicolumn{2}{|c|}{ Tanggal } & \multirow{2}{*}{$\begin{array}{l}\text { Umur } \\
\text { (Hari) }\end{array}$} & \multirow{2}{*}{$\begin{array}{c}\text { Slump } \\
\text { (cm) }\end{array}$} & \multirow{2}{*}{$\begin{array}{c}\text { Berat } \\
(\mathrm{kg})\end{array}$} & \multirow{2}{*}{$\begin{array}{c}\text { Force } \\
\text { Pressure } \\
(\mathbf{k N})\end{array}$} & \multicolumn{2}{|c|}{$\begin{array}{c}\text { Silinder } \\
\text { Kuat Tekan }\end{array}$} \\
\hline & & Pengecoran & Pengujian & & & & & $\left(\mathrm{kg} / \mathrm{cm}^{2}\right)$ & (MPa) \\
\hline 32. & $\mathrm{BC} 0,2-12$ & 02 Mei 2018 & 29 Mei 2018 & 28 & 7,5 & 12,87 & 555 & 317,47 & 31,75 \\
\hline 33. & $\mathrm{BC} 0,2-13$ & 02 Mei 2018 & 29 Mei 2018 & 28 & 7,5 & 12,75 & 540 & 311,70 & 31,17 \\
\hline 34. & $\mathrm{BC} 0,2-14$ & 02 Mei 2018 & 29 Mei 2018 & 28 & 7,5 & 12,69 & 535 & 308,81 & 30,88 \\
\hline 35. & $\mathrm{BC} 0,2-15$ & 02 Mei 2018 & 29 Mei 2018 & 28 & 7,5 & 12,88 & 550 & 317,47 & 30,75 \\
\hline 36. & $\mathrm{BC} 0,2-16$ & 02 Mei 2018 & 29 Mei 2018 & 28 & 7,5 & 12,75 & 540 & 311,70 & 31,17 \\
\hline 37. & $\mathrm{BC} 0,2-17$ & 02 Mei 2018 & 29 Mei 2018 & 28 & 7,5 & 12,87 & 550 & 317,47 & 31,17 \\
\hline 38. & $\mathrm{BC} 0,2-18$ & 02 Mei 2018 & 29 Mei 2018 & 28 & 7,5 & 12,86 & 550 & 317,47 & 31,75 \\
\hline 39. & $\mathrm{BC} 0,2-19$ & 02 Mei 2018 & 29 Mei 2018 & 28 & 7,5 & 12,75 & 540 & 311,70 & 31,17 \\
\hline 40. & $\mathrm{BC} 0,2-20$ & 02 Mei 2018 & 29 Mei 2018 & 28 & 7,5 & 12,84 & 545 & 314,58 & 31,46 \\
\hline 41. & $\mathrm{BC} 0,3-1$ & 26 April 2018 & 24 Mei 2018 & 28 & 7,5 & 12,75 & 545 & 314,58 & 31,46 \\
\hline 42. & $\mathrm{BC} 0,3-2$ & 26 April 2018 & 24 Mei 2018 & 28 & 7,5 & 12,78 & 545 & 314,58 & 31,46 \\
\hline 43. & $\mathrm{BC} 0,3-3$ & 26 April 2018 & 24 Mei 2018 & 28 & 7,5 & 12,72 & 545 & 314,58 & 31,46 \\
\hline 44. & $\mathrm{BC} 0,3-4$ & 26 April 2018 & 24 Mei 2018 & 28 & 7,5 & 12,74 & 555 & 320,36 & 32,04 \\
\hline 45. & $\mathrm{BC} 0,3-5$ & 26 April 2018 & 24 Mei 2018 & 28 & 7,5 & 12,87 & 560 & 323,24 & 32,32 \\
\hline 46. & $\mathrm{BC} 0,3-6$ & 26 April 2018 & 24 Mei 2018 & 28 & 7,5 & 12,85 & 560 & 323,24 & 32,32 \\
\hline 47. & $\mathrm{BC} 0,3-7$ & 26 April 2018 & 24 Mei 2018 & 28 & 7,5 & 12,86 & 560 & 323,24 & 32,32 \\
\hline 48. & BC0,3-8 & 26 April 2018 & 24 Mei 2018 & 28 & 7,5 & 12,84 & 555 & 320,36 & 32,04 \\
\hline 49. & $\mathrm{BC} 0,3-9$ & 26 April 2018 & 24 Mei 2018 & 28 & 7,5 & 12,85 & 565 & 326,13 & 32,61 \\
\hline 50. & $\mathrm{BC} 0,3-10$ & 26 April 2018 & 24 Mei 2018 & 28 & 7,5 & 12,88 & 550 & 317,47 & 31,75 \\
\hline 51. & $\mathrm{BC} 0,3-11$ & 26 April 2018 & 24 Mei 2018 & 28 & 7,5 & 12,92 & 570 & 332,01 & 32,90 \\
\hline 52. & $\mathrm{BC} 0,3-12$ & 26 April 2018 & 24 Mei 2018 & 28 & 7,5 & 12,85 & 560 & 323,24 & 32,32 \\
\hline 53. & $\mathrm{BC} 0,3-13$ & 26 April 2018 & 24 Mei 2018 & 28 & 7,5 & 12,75 & 545 & 314,58 & 31,46 \\
\hline 54. & $\mathrm{BC} 0,3-14$ & 26 April 2018 & 24 Mei 2018 & 28 & 7,5 & 12,90 & 575 & 331,90 & 33,19 \\
\hline 55. & $\mathrm{BC} 0,3-15$ & 26 April 2018 & 24 Mei 2018 & 28 & 7,5 & 12,90 & 570 & 329,01 & 32,90 \\
\hline 56. & $\mathrm{BC} 0,3-16$ & 26 April 2018 & 24 Mei 2018 & 28 & 7,5 & 12,81 & 565 & 326,13 & 32,61 \\
\hline 57. & $\mathrm{BC} 0,3-17$ & 26 April 2018 & 24 Mei 2018 & 28 & 7,5 & 12,92 & 570 & 329,01 & 32,90 \\
\hline 58. & $\mathrm{BC} 0,3-18$ & 26 April 2018 & 24 Mei 2018 & 28 & 7,5 & 12,84 & 555 & 320,36 & 32,04 \\
\hline 59. & $\mathrm{BC} 0,3-19$ & 26 April 2018 & 24 Mei 2018 & 28 & 7,5 & 12,86 & 565 & 326,13 & 32,61 \\
\hline 60. & $\mathrm{BC} 0,3-20$ & 26 April 2018 & 24 Mei 2018 & 28 & 7,5 & 12,86 & 560 & 323,24 & 32,32 \\
\hline
\end{tabular}

Sumber: Analisis Data (2018)

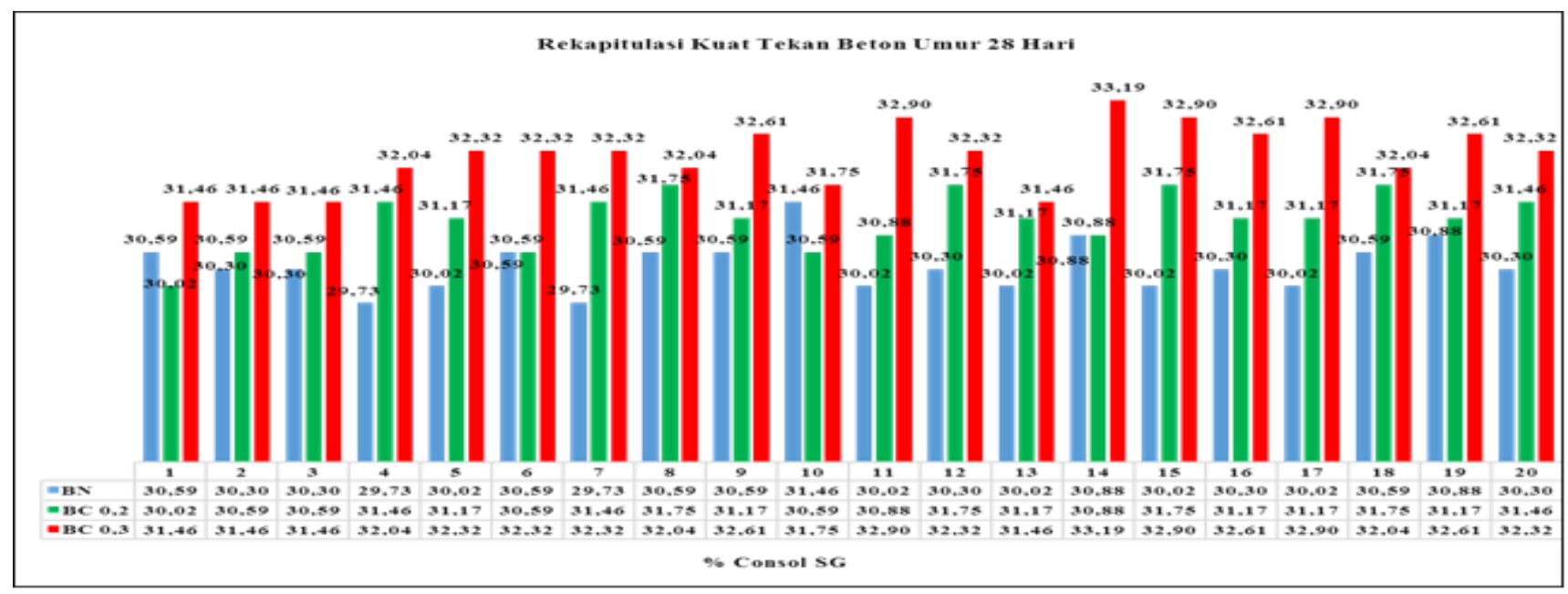

Gambar 4.3 Rekapitulasi Kuat Tekan Beton Umur 28 Hari Sumber: Analisis Data (2018) 
Dari diagram rekapitulasi ini dapat diketahui nilai kuat tekan beton untuk variasi campuran Consol SG semua keseluruhan mengalami peningkatan diitinjau dari kuat tekan beton normal. Pada kuat tekan campuran Consol SG $0,3 \%$ mengalami peningkatan paling tinggi sebesar 31,75 MPa pada uji sampel no. 8, 12, 15 dan 18. Sedangkan beton yang mengalami peningkatan paling tertinggi sebesar 33,19 MPa untuk variasi campuran Consol SG sebanyak $0.3 \%$ pada uji sampel no. 14. Hasil uji rekapitukasi ini terdapat kesamaan kuat tekan beton pada campuran Consol SG 0,2\% dengan kuat tekan beton normal sebesar 30,59 MPa pada sampel no. 6 dan sebesar 30,88 MPa no. 14. Sedangkan pada hasil rekapitulasi kuat tekan beton paling terendah ditunjukan pada sampel no. 5, 9, 13, 15, 17 sebesar 30,02 untuk beton normal, untuk campuran Consol SG 0,2\% kuat tekan beton paling rendah pada sampel no. 1 sebesar 30,02 MPa dan untuk campuran Consol SG 0,3\% kuat tekan beton yang terendah terdapat pada sampel no. 1, 2, 3, 13 sebesar 31,46 MPa. Untuk kuat tekan beton yang tidak melampui $30 \mathrm{MPa}$ atau gagal terdapat pada sampel no. 4 dan 7 sebesar 29,73 MPa.

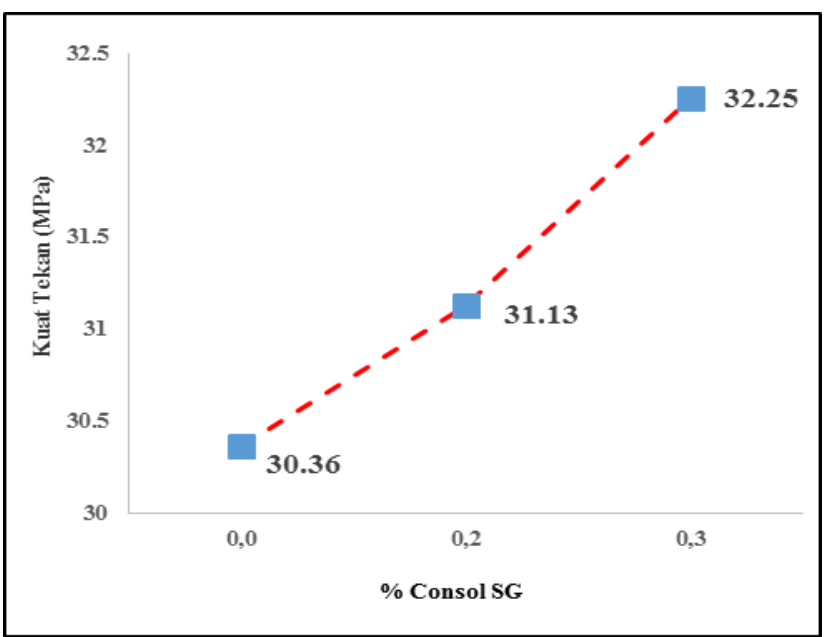

Gambar 4.5 Grafik kuat tekan rata-rata beton dengan penambahan Consol SG umur 28 hari.

Sumber: Analisis Data (2018)

Berdasarkan hasil pengujian diatas dengan penambahan Consol SG sebanyak 0,2\% mempunyai kuat tekan beton sebesar 31,13 MPa dibandingkan beton normal dengan kuat tekan beton sebesar 30,36 MPa sehingga meningkatan sebanyak 2,54\%. Pada beton dengan penambaan Consol SG sebesar 0,3\% dengan kuat tekan beton sebesar 32,25 MPa meningkat menjadi 6,22\% dari beton normal dengan kuat tekan beton sebesar 30,36 $\mathrm{MPa}$, sedangakan perbandingan penambahan Consol SG 0,2\% ke $0,3 \%$ Consol SG meningkat sebanyak 3,59\%. Hal ini dapat dilihat pengunaan Consol SG 0,3\% mempunyai kuat tekan paling tinggi.

\section{Uji Chi-Kuadrat}

Tabel 5. Hasil uji Chi-Kuadrat mengunakan campuran Consol SG

\begin{tabular}{|c|c|c|c|c|c|}
\hline Kode & $\mathbf{0}$ & $\mathbf{e}$ & & & $x^{2}$ \\
\hline $\begin{array}{c}\text { Benda } \\
\text { Uji }\end{array}$ & $\begin{array}{c}\text { Kuat } \\
\text { Tekan }\end{array}$ & $\begin{array}{l}\text { Rata- } \\
\text { Rata }\end{array}$ & $(0-e)^{\wedge} 2 / e$ & $x^{2}$ & $\begin{array}{l}(0,95 ; \\
(n-1))\end{array}$ \\
\hline BN-1 & 30,59 & \multirow{20}{*}{30,36} & 0,002 & \multirow{20}{*}{0,006} & \multirow{20}{*}{10,117} \\
\hline $\mathrm{BN}-2$ & 30,30 & & 0,000 & & \\
\hline BN-3 & 30,30 & & 0,000 & & \\
\hline $\mathrm{BN}-4$ & 29,72 & & 0,013 & & \\
\hline BN-5 & 30,02 & & 0,004 & & \\
\hline BN-6 & 30,59 & & 0,002 & & \\
\hline BN-7 & 29,72 & & 0,013 & & \\
\hline $\mathrm{BN}-8$ & 30,59 & & 0,002 & & \\
\hline $\mathrm{BN}-9$ & 30,59 & & 0,002 & & \\
\hline BN-10 & 31,46 & & 0,040 & & \\
\hline BN-11 & 30,02 & & 0,004 & & \\
\hline BN-12 & 30,30 & & 0,000 & & \\
\hline $\mathrm{BN}-13$ & 30,02 & & 0,004 & & \\
\hline BN-14 & 30,88 & & 0,009 & & \\
\hline $\mathrm{BN}-15$ & 30,02 & & 0,004 & & \\
\hline BN-16 & 30,30 & & 0,000 & & \\
\hline BN-17 & 30,02 & & 0,004 & & \\
\hline BN-18 & 30,59 & & 0,002 & & \\
\hline BN-19 & 30,88 & & 0,009 & & \\
\hline BN-20 & 30,30 & & 0,000 & & \\
\hline $\mathrm{BC} 0,2-1$ & 31,46 & \multirow{20}{*}{31,13} & 0,004 & \multirow{20}{*}{0,007} & \multirow{20}{*}{10,117} \\
\hline $\mathrm{BC} 0,2-2$ & 30,59 & & 0,009 & & \\
\hline $\mathrm{BC} 0,2-3$ & 30,59 & & 0,009 & & \\
\hline $\mathrm{BC} 0,2-4$ & 30,02 & & 0,040 & & \\
\hline $\mathrm{BC} 0,2-5$ & 31,17 & & 0,000 & & \\
\hline $\mathrm{BC} 0,2-6$ & 30,59 & & 0,009 & & \\
\hline $\mathrm{BC} 0,2-7$ & 31,46 & & 0,004 & & \\
\hline $\mathrm{BC} 0,2-8$ & 31,75 & & 0,012 & & \\
\hline BC0,2-9 & 31,17 & & 0,000 & & \\
\hline$\overline{\mathrm{BC} 0,2-10}$ & 30,59 & & 0,009 & & \\
\hline $\mathrm{BC} 0,2-11$ & 30,88 & & 0,002 & & \\
\hline $\mathrm{BC} 0,2-12$ & 31,75 & & 0,012 & & \\
\hline $\mathrm{BC} 0,2-13$ & 31,17 & & 0,000 & & \\
\hline $\mathrm{BC} 0,2-14$ & 30,88 & & 0,002 & & \\
\hline$\overline{\mathrm{BC} 0,2-15}$ & 30,75 & & 0,012 & & \\
\hline$\overline{\mathrm{BC} 0,2-16}$ & 31,17 & & 0,000 & & \\
\hline $\mathrm{BC} 0,2-17$ & 31,17 & & 0,000 & & \\
\hline$\overline{\mathrm{BC} 0,2-18}$ & 31,75 & & 0,012 & & \\
\hline BC0,2-19 & 31,17 & & 0,000 & & \\
\hline$\overline{\mathrm{BC}} 0,2-20$ & 31,46 & & 0,004 & & \\
\hline $\mathrm{BC} 0,3-1$ & 31,46 & \multirow{2}{*}{32,25} & 0,020 & \multirow[t]{2}{*}{0,008} & \multirow{2}{*}{10,117} \\
\hline $\mathrm{BC} 0,3-2$ & 31,46 & & 0,020 & & \\
\hline
\end{tabular}




\begin{tabular}{|c|c|c|c|c|c|}
\hline Kode & o & e & & & $x^{2}$ \\
\hline $\begin{array}{c}\text { Benda } \\
\text { Ujji }\end{array}$ & $\begin{array}{c}\text { Kuat } \\
\text { Tekan }\end{array}$ & $\begin{array}{l}\text { Rata- } \\
\text { Rata }\end{array}$ & $(0-e)^{\wedge} 2 / e$ & $\mathbf{x}^{2}$ & $\begin{array}{l}(0,95 ; \\
(n-1))\end{array}$ \\
\hline $\mathrm{BC} 0,3-3$ & 31,46 & & 0,020 & & \\
\hline $\mathrm{BC} 0,3-4$ & 32,04 & & 0,001 & & \\
\hline $\mathrm{BC} 0,3-5$ & 32,32 & & 0,000 & & \\
\hline BC0,3-6 & 32,32 & & 0,000 & & \\
\hline $\mathrm{BC} 0,3-7$ & 32,32 & & 0,000 & & \\
\hline $\mathrm{BC} 0,3-8$ & 32,04 & & 0,001 & & \\
\hline $\mathrm{BC} 0,3-9$ & 32,61 & & 0,004 & & \\
\hline$\overline{\mathrm{BC} 0,3-10}$ & 31,75 & & 0,008 & & \\
\hline$\overline{\mathrm{BC} 0,3-11}$ & 32,90 & & 0,013 & & \\
\hline$\overline{\mathrm{BC} 0,3-12}$ & 32,32 & & 0,000 & & \\
\hline$\overline{\mathrm{BC} 0,3-13}$ & 31,46 & & 0,020 & & \\
\hline$\overline{\mathrm{BC} 0,3-14}$ & 33,19 & & 0,027 & & \\
\hline$\overline{\mathrm{BC} 0,3-15}$ & 32,90 & & 0,013 & & \\
\hline$\overline{\mathrm{BC} 0,3-16}$ & 32,61 & & 0,004 & & \\
\hline$\overline{\mathrm{BC} 0,3-17}$ & 32,90 & & 0,013 & & \\
\hline$\overline{\mathrm{BC} 0,3-18}$ & 32,04 & & 0,001 & & \\
\hline$\overline{\mathrm{BC} 0,3-19}$ & 32,61 & & 0,004 & & \\
\hline$\overline{\mathrm{BC} 0,3-20}$ & 32,32 & & 0,000 & & \\
\hline
\end{tabular}

Sumber: Analisis Data (2018)

Dari tabel diatas dapat dilihat untuk benda uji sampel beton normal dan sampel beton tambahan Consol SG sampel dapat diterima semua dari $\mathrm{x}^{2}<\mathrm{x}^{2}$ $(0,95 ;(n-1)$.

\section{Uji T Satu Sampel}

Analisis uji $\mathrm{T}$ merupakan metode stastisik yang digunakan untuk menguji tingkat signifikan variasi Consol SG. Berdasarka hasil pengujian tabel diperoleh tingkat signifikan untuk variabel nilai $t$ hitung $<\mathrm{t}$ tabel dan $\mathrm{t}$ hitung > $\mathrm{t}$ tabel, pengujian hipotesis dilakukan untuk mengetahui adakah pengaruh setiap variasi Consol SG 0,2\% dan 0,3\% terhadap rata-rata kuat tekan beton.

\section{Hasil Pengujian}

Pada pengujian data variasi kuat tekan penambahan Consol SG sebesar 0,2\% dan 0,3\% terdapat pengaruh dari beton normal maka $\mathrm{H}_{1}$ diterima dan $\mathrm{H}_{0}$ ditolak.

Tabel 6. Hasil uji t beton campuran 0,2\%

One-Sample Statistics

\begin{tabular}{ccccc}
\hline & $N$ & Mean & Std. Deviation & Std. Error Mean \\
\hline Beton Campuran 0,2\% & 20 & 31,1270 &, 48107 &, 10757 \\
\hline
\end{tabular}

One-Sample Test

\begin{tabular}{|c|c|c|c|c|c|c|}
\hline & \multicolumn{6}{|c|}{ Test Value $=31,13$} \\
\hline & \multirow[b]{2}{*}{$t$} & \multirow[b]{2}{*}{$d f$} & \multirow[b]{2}{*}{ Sig. (2-tailed) } & \multirow{2}{*}{$\begin{array}{c}\text { Mean } \\
\text { Difference }\end{array}$} & \multicolumn{2}{|c|}{$\begin{array}{l}\text { 95\% Confidence Interval of the } \\
\text { Difference }\end{array}$} \\
\hline & & & & & Lower & Upper \\
\hline Beton Campuran 0,2\% &,- 028 & 19 & ,978 &,- 00300 &,- 2281 & ,2221 \\
\hline
\end{tabular}


Tabel 7. Hasil uji t beton campuran 0,3\%

\section{One-Sample Statistics}

\begin{tabular}{ccccc}
\hline & $N$ & Mean & Std. Deviation & Std. Error Mean \\
\hline Beton Campuran 0,3\% & 20 & 32,2515 &, 53524 &, 11968 \\
\hline
\end{tabular}

One-Sample Test

\begin{tabular}{|c|c|c|c|c|c|c|}
\hline & \multicolumn{6}{|c|}{ Test Value $=32,25$} \\
\hline & \multirow[b]{2}{*}{$t$} & \multirow[b]{2}{*}{$d f$} & \multirow[b]{2}{*}{ Sig. (2-tailed) } & \multirow[b]{2}{*}{ Mean Difference } & \multicolumn{2}{|c|}{$\begin{array}{c}95 \% \text { Confidence Interval of the } \\
\text { Difference }\end{array}$} \\
\hline & & & & & Lower & Upper \\
\hline Beton Campuran 0,3\% & 013 & 19 & ,990 &, 00150 &,- 2490 & 2520 \\
\hline
\end{tabular}

Sumber: Analisis Data (2018)

\section{KESIMPULAN}

1. Penggunaan bahan tambah campuran Consol SG sebesar $0,2 \%$ dapat meningkatkan kuat tekan beton dari beton normal 30,36 $\mathrm{MPa}$ menjadi 31,13 $\mathrm{MPa}$ (naik 2,54\%). Sedangkan variasi campuran Consol SG sebesar 0,3\% dengan nilai kuat tekan sebesar 32,25 MPa (naik 6,22\% dari beton normal).

2. Campuran Consol SG 0,2\% nilai t hitung < t tabel ($0,28<2,093)$ dan nilai Sign $(0,978>0,05)$. Sedangkan campuran Consol SG 0,3\% nilai t hitung < t tabel $(0.13<2,093)$ dan nilai Sign $(0,990>0,05)$, maka $\mathrm{H}_{1}$ diterima dan $\mathrm{H}_{0}$ ditolak. Sehingga pada pengujian data variasi kuat tekan penambahan Consol SG sebesar $0,2 \%$ dan $0,3 \%$ terdapat pengaruh dari beton normal.

\section{SARAN}

1. Penelitian selanjutnya ditambahkan sampel dengan campuran lain sebesar 0,50\% atau lebih agar dapat memperoleh campuran yang optimum.

\section{DAFTAR PUSTAKA}

Anonim. 2002. Tata Cara Perhitungan Struktur Beton Untuk Bangunan Gedung. SNI 03-2847-2002. Jakarta.

Anonim. 1971. Peraturan Beton Bertulang Indonesia. Bandung: Departemen Pekerjaan Umum dan Tenaga Listrik Direktorat Jendral Ciptakarya Lembaga Penyelidikan Masalah Bangunan.

Anonim. 1990. Metode Pengujian Berat Jenis Dan Penyerapan Air Agregat Kasar. SNI 03-19691990. Jakarta.

Anonim. 1990. Metode Pengujian Berat Jenis Dan Penyerapan Air Agregat Halus. SNI 03-19701990. Jakarta.

Anonim. 1990. Metode Pengujian Kadar Air Agregat. SNI 03-1971-1990. Jakarta.

Anonim. 1992. Metode Uji Bahan Organik Dalam Agregat Halus Untuk Beton. SNI 03-2816-1992. Jakarta.
Anonim. 1990. Metode Pengujian Tentang Analisis Saringan Agregat Halus Dan Kasar. SNI 03-19681990. Jakarta.

Anonim. 1990. Metode Pengujian Slump Beton. SNI 031972-1990.Jakarta.

Anonim. 2000. Tata Cara Pembuatan Rencana Campuran Beton Normal. SNI 03-2834-2000. Jakarta.

Anonim. 2011. Tata Cara Pembuatan Dan Perawatan Benda Uji Beton Di Laboratorium. SNI 03-2492011. Jakarta.

Anonim. 1996. Metode Pengujian Jumlah Bahan Dalam Agregat Yang Lolos Saringan No. 200 (0,075 Mm). SNI 03-4142-1996. Jakarta.

Anonim. 1998. Metode Pengujian Bobot Isi Dan Rongga Udara Dalam Agregat. SNI 03-4804-1998.

Neville, A.M, and J.J. Brook. 1987. Concrete Technology. New York: Longman Scientific \& Technical.

Murdock, L. J. dan Brook, K. M. 1999. Bahan dan Praktek Beton, Jakarta: Erlangga.

Herrhyanto, Nar dan Tuti, Gantini. 2015. Analisi Data Kuantitatif Dengan Stastistik Deskritif, Bandung: Yrama Widya.

Siegel, Sidney.1994. Statistik Nonparameter, Jakarta: Gramedia.

Tamboto, Winny J. dan Tenda, Ruddy. 2014. Pengaruh Dimensi Benda Uji Terhadap Kuat Tekan Beton. Jurnal Ilmiah 2 (7): 344-351, Jurusan Teknik Sipil, Universitas Sam Ratulangi Manado.

Aulia, Mohamad, Donie. 2012. Studi Eksperimental Permeabilitas Dan Kuat Tekan Beton K-450 Menggunakan Zat Adiktif Conplast WP4211. Majalah ilmiah. 10 (2): 211-222, Jurusan Teknik Sipil, Universitas Komputer Indonesia.

Alvan, Syahreza. 2005. Pengaruh Penambahan Zat Aditif Terhadap Permeabilitas Beton Dan Kuat Tekan Beton, Tesis, Jurusan Teknik Sipil, Universitas Sumatera Utara, Medan. 